\title{
HEMOCHROMATOSIS MUTATIONS, DEMENTIA AND BRAIN IRON DEPOSITION: A PROSPECTIVE COHORT STUDY
}

David Melzer, MBBCh ${ }^{1,2}$; Janice L Atkins, $\mathrm{PhD}^{1}$; Luke C Pilling, $\mathrm{PhD}^{1}$; Christine J Heales, $\mathrm{PhD}^{3}$;

Sharon Savage $\mathrm{PhD}^{4}$; Chia-Ling Kuo, $\mathrm{PhD}^{5}$; George A Kuchel${ }^{2}$; MD, David C Steffens, $\mathrm{MD}^{6}$

${ }^{1}$ Epidemiology and Public Health Group, University of Exeter Medical School, Exeter, UK

${ }^{2}$ Center on Aging, University of Connecticut Health Center, Farmington, CT, USA

${ }^{3}$ Medical Imaging, College of Medicine and Health, University of Exeter, Exeter, UK

${ }^{4}$ Psychology Department, University of Exeter, Exeter, UK

${ }^{5}$ Biostatistics Center, Connecticut Convergence Institute for Translation in Regenerative Engineering,

UConn Health, Farmington, CT, USA

${ }^{6}$ Department of Psychiatry, University of Connecticut Health Center, Farmington, CT USA

Corresponding author: Professor David Melzer, Epidemiology and Public Health Group, University of Exeter Medical School, College House, St. Luke's Campus, Exeter, EX1 2LU, UK.

Email: D.Melzer@exeter.ac.uk

Manuscript word count: 2949 words in main text 
medRxiv preprint doi: https://doi.org/10.1101/2020.06.18.20134536; this version posted June 20, 2020. The copyright holder for this preprint (which was not certified by peer review) is the author/funder, who has granted medRxiv a license to display the preprint in perpetuity.

\section{It is made available under a CC-BY-NC-ND 4.0 International license .}

\section{Key Points}

Question: Is the hemochromatosis HFE p.C282Y homozygous variant in men associated with brain MRI features and incident dementia?

Findings: On MRI, p.C282Y homozygote males had evidence of more iron deposition in areas including the thalamus, putamen and hippocampus, plus smaller putamen gray matter volumes, compared to men without HFE mutations. In 451,186 UK Biobank participants during the mean 8.8 year follow-up, incident dementia diagnoses were more than twice as common in the 1,294 homozygous men.

Meaning: As iron overload in hemochromatosis is treatable, early intervention may prevent or limit related brain pathology in male HFE p.C282Y homozygotes. 
medRxiv preprint doi: https://doi.org/10.1101/2020.06.18.20134536; this version posted June 20, 2020. The copyright holder for this preprint (which was not certified by peer review) is the author/funder, who has granted medRxiv a license to display the preprint in perpetuity.

It is made available under a CC-BY-NC-ND 4.0 International license .

\begin{abstract}
Importance: Brain iron deposition is common in dementia, but its causal significance is uncertain. The HFE p.C282Y homozygous mutation in European ancestry populations can lead to iron overload and hemochromatosis, mainly in males. Data on brain outcomes in homozygotes are scarce.
\end{abstract}

Objective: To estimate HFE variant associations with MRI features plus incident dementia diagnoses during follow-up in a large community based cohort.

Design: UK Biobank cohort with follow-up in routine hospitalization records (mean 8.8 years). MRI imaging available on a participant subset scanned 2014 to 2018.

Setting: Community cohort participants across England, Wales and Scotland.

Participants: European ancestry participants $(n=451,186)$ aged 40 to 70 years at baseline, including 2,890 p.C282Y homozygotes (predominantly without baseline haemochromatosis diagnoses). MRI scanning on 9,464 males and 10,475 females, including 40 male and 75 female p.C282Y homozygotes.

Exposure: HFE C282Y and H63D genetic variants

Main outcome and measures: Brain MRI site specific T2* measures (lower values associated with iron deposition) and gray matter volumes. Incident dementia diagnoses during follow-up.

Results: Male p.C282Y homozygotes had lower T2* measures in several brain areas including the thalamus (beta $=-1.04$ standard deviations, $95 \% \mathrm{Cl}-1.33$ to -0.76 , multiple testing adjusted $\mathrm{p}$ value $\left.=4.9^{*} 10^{-10}\right)$, putamen and hippocampus, compared to those without HFE mutations. Male homozygotes also had smaller gray matter volumes in the putamen (beta $-0.80 \mathrm{sd}, 95 \% \mathrm{Cl}-1.12$ to 0.47 , adjusted $p=2.2^{*} 10^{-4}$ ) and ventral striatum.

Diagnoses of incident dementia (Hazard Ratio HR=2.27; $95 \% \mathrm{Cl} 1.36$ to $3.80, \mathrm{p}=0.002$ ) were more common in p.C282Y homozygous men, as were delirium diagnoses ( $\mathrm{HR}=2.04, \mathrm{Cl} 1.09$ to 3.82 , $p=0.03$ ), but there was no association with Stroke.

In p.C282Y homozygote females and p.C282Y/H63D heterozygotes, MRI associations were less marked. 
medRxiv preprint doi: https://doi.org/10.1101/2020.06.18.20134536; this version posted June 20, 2020. The copyright holder for this preprint (which was not certified by peer review) is the author/funder, who has granted medRxiv a license to display the preprint in perpetuity. It is made available under a CC-BY-NC-ND 4.0 International license.

Conclusion and Relevance: In a community sample, men with the HFE p.C282Y homozygote genotype had more brain iron deposition, smaller specific gray matter volumes, and increased incidence of dementia. As iron overload in hemochromatosis is treatable, early intervention may prevent or limit related brain pathology in male HFE p.C282Y homozygotes. 
medRxiv preprint doi: https://doi.org/10.1101/2020.06.18.20134536; this version posted June 20, 2020. The copyright holder for this preprint (which was not certified by peer review) is the author/funder, who has granted medRxiv a license to display the preprint in perpetuity.

It is made available under a CC-BY-NC-ND 4.0 International license .

\section{Introduction}

Iron has been linked to dementia and other neurodegenerative diseases, with roles in oxygen transport, myelin production plus synthesis and metabolism of neurotransmitters ${ }^{1-3}$. Several rare genetic 'Neurodegeneration with Brain Iron Accumulation' syndromes have been described ${ }^{4}$. Iron accumulation in specific brain areas is found in Alzheimer's disease (the most common form of dementia), beyond normal accumulations seen in aging ${ }^{5}$, and these iron accumulations are associated with amyloid plaques and tau aggregation ${ }^{5}$. Chelator treatment to remove iron has shown promise in Alzheimer's disease animal models ${ }^{5}$ and in human randomized trials, with some evidence of slowing of cognitive decline ${ }^{6}$.

The homeostatic iron regulator 'HFE' gene p.C282Y variant relaxes controls iron absorption from the gut, leading to moderately raised serum iron levels ${ }^{7}$ in heterozygotes. In homozygote males especially, the variants can result in iron overload and iron deposition in many tissues ${ }^{8}$. Male p.C282Y homozygotes are at substantially increased risks of liver cirrhosis and liver carcinomas, arthritis, osteoporosis, pneumonia and diabetes ${ }^{9}$. Iron overload in p.C282Y homozygote women is less common ${ }^{7}$, likely due to iron losses in menstruation, and iron overload is unusual in p.C282Y/H63D compound heterozygotes ${ }^{9}$. In northern European Ancestry populations, the p.C282Y variant is carried by $10-15 \%$, with approximately 1 in $150(0.67 \%)$ being homozygous ${ }^{10}$. In North America, p.C282Y homozygosity prevalence is $0.44 \%$ in non-Hispanic whites, but much less common in other ancestry groups ${ }^{7}$. Iron overload in hemochromatosis is prevented and treated with venesection $^{8}$, but many patients are currently diagnosed only after irreversible morbidity has developed.

There have been several reports of associations between HFE genotypes and dementia, but a recent multi-study case-control meta-analysis of the p.C282Y mutation rs1800562 and Alzheimer's disease reported no association. However, this analysis tested overall genotype associations (which are dominated by the large numbers of heterozygotes) and did not analyze homozygote males separately ${ }^{11}$. It therefore remains unclear whether p.C282Y homozygotes have increased risks for brain outcomes. 
medRxiv preprint doi: https://doi.org/10.1101/2020.06.18.20134536; this version posted June 20, 2020. The copyright holder for this preprint (which was not certified by peer review) is the author/funder, who has granted medRxiv a license to display the preprint in perpetuity.

It is made available under a CC-BY-NC-ND 4.0 International license .

Given the paucity of evidence, we aimed to test associations between HFE p.C282Y and p.H63D status and; 1) brain features in the MRI subset, and 2) incident dementia recorded during hospitalization in the overall sample. We used data from UK Biobank (UKB) European descent participants $(n=451,186)$, including $16,534 \mathrm{MRI}$ imaging volunteers. We hypothesized that p.C282Y homozygous males would be at most risk from brain iron deposition plus dementia during follow-up, as this group has substantially higher risks of other hemochromatosis morbidities ${ }^{9}$ compared to women p.C282Y homozygotes or p.C282Y/H63D heterozygotes. UKB consent does not allow individual feedback of genotypes, so the medical care and records used in the analyses were not altered by UKB identified genotypes.

\section{Methods}

Ethical approval

UKB ethical approval was from the North West Multi-Centre Research Ethics Committee. The current analysis was approved under UKB application 14631 (PI David Melzer).

\section{Data and Participants}

UKB included 502,634 volunteers aged 40 to 70 years old at recruitment, living near 22 assessment centers in England, Scotland and Wales ${ }^{12}$. Baseline assessments (2006 to 2010) included disease history ${ }^{12}$ and participants consented to genotyping, plus record linkage to the UK National Health Service hospitalization routine datasets. As HFE p.C282Y mutations are common only in European ancestry groups ${ }^{7}$, we used data for the 451,186 European ancestries participants with HFE C282Y (rs1800562) genotype information, and also for HFE p.H63D (rs1799945): see Supplementary Methods for details. Data for MRI analyses were from participants who met the above criteria and volunteered for MRI (scanned May 2014 to 2018): main analyses included 19,944 such participants, with an additional analysis of data from the 16,534 with full data on all derived brain MRI measures.

\section{Outcomes}

Magnetic Resonance Imaging (MRI) phenotypes were from the UKB brain image-processing pipeline $^{13}$. A standard Siemens Skyra 3T running VD13A SP4, with Siemens 32-channel RF receive head coil was used. Measures included $\mathrm{T}^{*}$ signal loss, an indicator of magnetic susceptibility influenced mainly by iron in deoxyhemoglobin, storage proteins and myelin ${ }^{14}$. Given strong correlations between right and left hemisphere $\mathrm{T}^{*}$ iron deposition measures (correlation 0.48 to 0.79 , 
medRxiv preprint doi: https://doi.org/10.1101/2020.06.18.20134536; this version posted June 20, 2020. The copyright holder for this preprint (which was not certified by peer review) is the author/funder, who has granted medRxiv a license to display the preprint in perpetuity.

It is made available under a CC-BY-NC-ND 4.0 International license .

all $p<0.0001$ ), mean values for right and left hemisphere matching variables were used in primary analyses, to reduce multiple statistical testing.

\section{Diagnoses and Follow-up:}

Incident diagnoses were from UKB follow-up hospitalization routine datasets to March 2017 for England (Hospital Episode Statistics), October 2016 for Scotland (Scottish Morbidity Record) and February 2016 for Wales (Patient Episode Database for Wales). The maximum inpatient follow-up was 11.0 years, mean 8.0 years. Incident diagnoses were ascertained from recorded International Classification of Disease $10^{\text {th }}$ revision codes. We used F00* F01* F02* F03*; G30* to ascertain dementia diagnoses. We also ascertained diagnoses of Mild Cognitive Impairment (MCI; ICD-10 codes: F06.7), delirium (ICD-10 codes: F05*) and stroke or Transient Ischemic Attack (TIA) (ICD-10 codes: G45-G46*; $\left.161^{*} ; 163^{*}\right)$, as these conditions are correlated with dementia risk. Analyses of each incident condition excluded individuals with the respective prevalent diagnoses at baseline, based on participant responses at baseline interview plus ICD-10 coded hospitalization records from 1996 to baseline interview (see Supplementary Methods). For example participants who reported having doctor diagnosed dementia at the baseline interview and those who had hospitalization data with dementia diagnostic codes before baseline interview were excluded from incident dementia analyses. Dementia diagnosis accuracy has been validated in English hospital records (sensitivity 78\%, specificity $92 \%)^{15}$ and Scottish routine data (positive predictive value $\left.87 \%\right)^{16}$. In our preparatory analyses, Apolipoprotein $E(A p o E)$ e4/e4 type was strongly associated with the recorded incident dementia diagnoses (OR=7.5 95\% $\mathrm{Cl}: 6.4$ to 8.7 , versus e3/e3), as expected.

\section{Statistical analysis}

Given that HFE p.C282Y homozygotes (mainly men) are at most risk for iron overload, followed by p.C282Y/H63D, analyses and reporting focusses on men and women with these genotypes, compared to participants with neither p.C282Y nor p.H63D mutations. See Supplementary Methods for details and Supplementary Table 1 for participant numbers for all genotype groups.

For MRI analyses, we hypothesized that $\mathrm{T}^{*}$ iron deposition associated measures were most likely to be associated with HFE genotypes, followed by gray matter volumes. However, to be conservative and complete, we analyzed all available UK Biobank produced MRI measures, with Benjamini- 
medRxiv preprint doi: https://doi.org/10.1101/2020.06.18.20134536; this version posted June 20, 2020. The copyright holder for this preprint (which was not certified by peer review) is the author/funder, who has granted medRxiv a license to display the preprint in perpetuity.

It is made available under a CC-BY-NC-ND 4.0 International license .

Hochberg adjustment for multiple testing applied across all imaging phenotype associations ( $n=481$ tests in p.C282Y homozygotes), to limit the false discovery rate. Linear regression was used to test associations between HFE C282Y \& H63D genotypes and MRI measures (after calculating mean left and right measures as above), compared with having neither mutations, in males and females separately. MRI measures were quantile normalized and z-transformed before analysis.

Cox proportional hazards regression was used to test genotype associations with incident diagnoses. All models were stratified by sex, and adjusted for population genetics sub-structure using the first ten principal components generated in European-descent participants, genotyping microarray (Affymetrix Axiom array for $90 \%$ and Affymetrix BiLEVE array for $10 \%$ of participants, sharing $>95 \%$ content), assessment center, plus age at assessment. There were no violations of proportional hazards assumptions for principal outcome (dementia and Parkinson's) in Cox models. Analyses used Stata v14.1, and `stcox` function for Cox models. In sensitivity analysis, we also excluded one randomly selected participant from each pair of participants related to the third degree $(n=71,638)$ leaving 379,548 unrelated participants for sensitivity analyses. This was to avoid possible inflation of associations from family relatedness.

Missing data: We excluded the relatively small number of participants without imputed genotypes $(n=15 \sqsupset 233 / 502 \sqsupset 642,3.0 \%)$ and those with imprecise p.C282Y imputation ( $n=183 / 487 \sqsupset 409,0.04 \%)$. UK Biobank derived MRI gray matter volume measures were available for slightly more participants than for $\mathrm{T}^{*}$ measures (Table 2): we therefore provide analyses of all participant data for each brain MRI separate measure, and additional analyses including only participants with a full set of all MRI measures. Diagnosis data during follow-up were from all available hospital inpatient record data.

\section{Results}

Analyses of incident diagnoses during follow-up included 451,186 UKB participants of European descent, aged 40 to 70 years at baseline (mean 56.8 years, SD 8.0)(Table 1). Homozygous p.C282Y status was present in $0.64 \%(2890 / 451,186)$ of the sample, with $14.2 \%(64,440)$ of the sample being heterozygous (including 10,701 p.C282Y/H63D compound heterozygotes) (see Supplementary Table 1 for details of all HFE genotypes, including heterozygotes). Only $12.1 \%(156 / 1294)$ of male and $3.4 \%$ (54/1596) of female p.C282Y homozygotes had been diagnosed with hemochromatosis (Table 1) at 
medRxiv preprint doi: https://doi.org/10.1101/2020.06.18.20134536; this version posted June 20, 2020. The copyright holder for this preprint (which was not certified by peer review) is the author/funder, who has granted medRxiv a license to display the preprint in perpetuity.

It is made available under a CC-BY-NC-ND 4.0 International license .

baseline. Data from the brain MRI subset were available for 9,464 males and 10,475 females meeting inclusion criteria (Table 1), including 40 male and 75 female p.C282Y homozygotes.

\section{MRI measure associations}

Overall participation in MRI was slightly more common in males (OR=1.09 95\%Cl 1.06 to 1.12$)$ and slightly less common with advancing age (in years, OR=0.973 Cl 0.971 to 0.975 ). However, male p.C282Y homozygotes were less likely to participate in the MRI (3.1\% of 1,294 homozygote males versus $4.6 \%$ of men with neither p.C282Y nor p.H63D mutations: $\mathrm{OR}=0.62 \mathrm{Cl} 0.45$ to 0.85 ). Only three male p.C282Y homozygote MRI participants (of the 40, 7.5\%) were diagnosed with hemochromatosis at baseline compared to $12.1 \%$ in the 1,294 homozygote males included in diagnosis analyses. There were no p.C282Y homozygote males with incident dementia in the MRI sub-sample. Female p.C282Y homozygote participation in the MRI subset was similar to participation with neither HFE mutation.

Data on T2* signal loss (lower measures associated with more iron deposition) were available for 37 male and 69 female homozygotes (Table 2). T2* measures were substantially lower in male p.C282Y homozygotes within the thalamus (beta $=-1.04$ standard deviations 'sd', $95 \% \mathrm{Cl}-1.33$ to -0.76 , Benjamini-Hochberg multiple testing adjusted $p$-value $=4.9 * 10^{-10}$ ), plus the putamen, caudate and accumbens, compared to neither mutations. There were also lower $\mathrm{T}^{*}$ measures in the hippocampus in p.C282Y homozygote men (beta $=-0.42 \mathrm{sd}, 95 \% \mathrm{Cl} \quad-0.67$ to -0.17 , adjusted $\mathrm{p}=0.042$ ). For illustration (Figure 1), we present T2 fluid attenuated inversion recovery (FLAIR) images from a male homozygote with the nearest to group $\mathrm{T}^{*}$ putamen measure, versus a similar image from an age and sex-matched participant without HFE mutations. Smaller gray matter volumes were found in the putamen of male C282Y homozygotes (beta $-0.80 \mathrm{sd}, 95 \% \mathrm{Cl}-1.12$ to -0.47 , adjusted $\mathrm{p}=2.2^{*} 10^{-4}$ ), and gray matter volumes were smaller in several cerebellar regions and the ventral striatum, compared to neither variants (see Supplementary Tables 2 and 3 for full results). Results of left and right hemisphere measures analyzed separately were consistent with the findings presented above (Supplementary Tables 4 and 5). Results of a sensitivity analysis in participants with complete MRI measures (Supplementary Tables 6 and 7) were also similar to those presented above. 
medRxiv preprint doi: https://doi.org/10.1101/2020.06.18.20134536; this version posted June 20, 2020. The copyright holder for this preprint (which was not certified by peer review) is the author/funder, who has granted medRxiv a license to display the preprint in perpetuity.

It is made available under a CC-BY-NC-ND 4.0 International license .

In women (Table 2), there were also associations between p.C282Y homozygote status and T2* measures within the putamen, thalamus, caudate, and pallidum (Table 2). Lower gray matter volumes were observed in the putamen, ventral striatum and regions of the cerebellum (adjusted $\mathrm{p}<0.05)$. In male and female $\mathrm{C} 282 \mathrm{Y} / \mathrm{H} 63 \mathrm{D}$ heterozygotes and in the other HFE genotype groups there were similar associations, but effect sizes were substantially smaller $(\leq 0.5$ standard deviations - see Supplementary Tables 2 and 3).

\section{Disease associations}

In the overall UKB sample there were 1,898 participants newly diagnosed with dementia during the mean 8 year follow-up (Table 1; Supplementary Table 1). Male C282Y homozygotes ( $0.64 \%$ of the male study population) made up $1.43 \%(15 / 1,049)$ of male participants with incident dementia (Table 1).

Male p.C282Y homozygotes had increased hazards for incident dementia (HR 2.27, 95\% $\mathrm{Cl} 1.36$ to 3.80, $p=0.002$, compared to those with neither p.C282y nor p.H63D) (Figure 2). To remove potential bias from multiple family members, in a sensitivity analysis we included only one participant from those related to the third degree or closer ( $n=174,898$ after exclusions): the male homozygous association with dementia was similar ( $\mathrm{HR}=2.07,95 \% \mathrm{Cl}: 1.14$ to $3.77, \mathrm{p}=0.02)$. To extend the evidence of association between p.C282Y homozygosity and dementia in men, we additionally tested associations with Mild Cognitive Impairment, Delirium, and Stroke or TIA diagnoses. There were increase hazards for diagnosis of incident delirium in p.C282Y homozygote males (HR 2.04, $\mathrm{Cl} 1.09$ to 3.82, $\mathrm{p}=0.03)$ and a similar but non-significant trend with Mild Cognitive Impairment $(\mathrm{HR} 2.63 \mathrm{Cl}$

0.83 to 8.33 ). There was no association with Stroke and Transient Ischemic Attack diagnoses. In female C282Y homozygotes and the heterozygote HFE variants in either sex, there were no associations with dementia (Figure 2) (see Supplementary Table 8).

\section{Discussion}

We aimed to estimate hemochromatosis genotype associations with brain MRI measures and incident dementia in the UKB community genotyped cohort. T2* signal loss occurs in the presence of magnetic susceptibility changes in the brain, caused mainly by iron $^{14}$. In the MRI subsample, we found substantial associations in p.C282Y homozygote men with lower T2* measures (associated 
medRxiv preprint doi: https://doi.org/10.1101/2020.06.18.20134536; this version posted June 20, 2020. The copyright holder for this preprint (which was not certified by peer review) is the author/funder, who has granted medRxiv a license to display the preprint in perpetuity.

It is made available under a CC-BY-NC-ND 4.0 International license .

with greater iron deposition) in several areas involved in dementia, including the hippocampus. In addition, we found lower gray matter volumes including in the putamen and ventral striatum. In the main UKB sample $(n=451,186)$ we found a doubling of hazard for incident dementia diagnoses during hospitalization in p.C282Y homozygote men (ascertained during the mean 8 year follow-up), plus increased hazards for delirium, for which dementia is a major risk factor ${ }^{17}$. Overall, these results suggest that p.C282Y homozygosity is a significant risk factor for dementia in men with European ancestries. Associations between p.C282Y heterozygous status and dementia were not statistically significant.

It is difficult to compare our findings with similar community samples with sufficient numbers of p.C282Y homozygotes because UKB contains nearly 10 times more such participants than the previously largest similar study ${ }^{9}$, yielding far more statistical power to detect associations. As noted, iron deposition has been linked to core Alzheimer's disease pathologies, with iron being bound by Alzheimer's associated amyloid $\beta$ and tau, and involved in formation of oligomeric tau ${ }^{2}$. A recent meta-analysis of the p.C282Y variant (HFE rs1800562, plus the transferrin variant rs1049296) found no association with Alzheimer's disease, but no results were provided on the homozygote mutation in either men or women. In UK Biobank, a similar analysis of rs1800562 also produces no overall association (unadjusted $p$-value $=0.021$ ) with incident dementia, but this is because there were 64,458 heterozygotes (Supplementary table 1) and only 2890 homozygotes in analyses. An earlier metaanalysis ${ }^{18}$ of $\mathrm{p.C282Y}$ dementia association studies included data on only 18 p.C282Y homozygote cases and 37 controls and reported no association, while another meta-analysis ${ }^{19}$ studied 16 p.C282Y heterozygotes and reported reduced Alzheimer's disease risks, but included no data on homozygotes.

The brain areas with associated iron deposition in p.C282Y homozygote men included the hippocampus, a key cognitive area ${ }^{20}$. Iron accumulation in p.C282Y homozygote males occurred in the thalamus, an area frequently affected in early Alzheimer's disease ${ }^{21}$, as well as in the putamen, where iron accumulation occurs with aging ${ }^{22}$ and in depression ${ }^{23}$. Smaller putamen gray matter volumes have been reported in neurodegenerative disorders ${ }^{24}$, including Alzheimer's ${ }^{20}$.

Limitations 
medRxiv preprint doi: https://doi.org/10.1101/2020.06.18.20134536; this version posted June 20, 2020. The copyright holder for this preprint (which was not certified by peer review) is the author/funder, who has granted medRxiv a license to display the preprint in perpetuity.

It is made available under a CC-BY-NC-ND 4.0 International license .

The main limitation of this analysis is that participant ages at the end of follow-up were relatively young (mean 65.3 years old, range 40.8 to 80.9 ), and longer follow-up will be needed to exclude associations with dementia, especially in p.C282Y homozygous women. Dementia sub-type data are limited in UKB hospitalization records: within the male p.C282Y homozygotes with dementia, specific diagnoses were Alzheimer's disease ( $n=4$, ICD-10 F00.2 \& ICD-10 G30.9); vascular dementia, unspecified ( $n=3$, ICD-10 F01.9); Dementia in Parkinson's disease ( $n=1$, ICD-10 F02.3); dementia in other specified diseases classified elsewhere ( $n=1$, ICD-10 F02.8) and unspecified dementia ( $n=6$, ICD-10 F03). More work is needed to systematically assess specific dementia pathologies, including in those not hospitalized. Also, UKB volunteers tended to have somewhat less morbidity and lower prevalence of health risk factors at baseline compared to the UK population ${ }^{25}$, but this should have limited impact on our estimates, which are based on incident diagnoses during follow-up only in those free of dementia diagnoses at baseline. We cannot relate MRI features to incident diagnoses in the same study participants: there were no dementia diagnoses in p.C282Y homozygote men in our MRI sub-sample, likely due to the small sample size and limited follow-up time thus far, although this does have the advantage of avoiding double counting of homozygotes with dementia across the overall and MRI subset analyses.

The evidence presented of excess brain pathology is from HFE p.C282Y homozygote males identified through community genotyping who were predominantly not diagnosed with hemochromatosis at UK Biobank baseline. These findings add to the extensive excess morbidity reported in p.C282Y homozygote males, including excess liver disease, arthritis, diabetes, osteoporosis, and pneumonia ${ }^{9}$. Iron excess in p.C282Y homozygotes is usually easily and safely treated with venesection ${ }^{8}$. HFE p.C282Y associated dementia may therefore be a treatable and preventable form of dementia, but clinical trials are needed to confirm this. Our findings add to the case for systematic early ascertainment of the hemochromatosis homozygote variant, especially in men.

\section{Conclusions}

Men with the HFE p.C282Y homozygous mutation developed substantially more marked brain iron deposition in dementia relevant brain areas, plus specific lower gray matter volumes. In addition, p.C282Y homozygote men were more likely to be diagnosed with dementia during the UK Biobank follow-up period. In female p.C282Y homozygotes and in heterozygotes, brain iron deposition 
medRxiv preprint doi: https://doi.org/10.1101/2020.06.18.20134536; this version posted June 20, 2020. The copyright holder for this preprint (which was not certified by peer review) is the author/funder, who has granted medRxiv a license to display the preprint in perpetuity.

$$
\text { It is made available under a CC-BY-NC-ND } 4.0 \text { International license. }
$$

appeared less marked, but longer follow-up will be needed to exclude associations with dementia. As the iron overload is easily treated with phlebotomy, early intervention in pC282Y homozygotes may prevent and limit the associated brain pathology and dementia diagnoses. 
medRxiv preprint doi: https://doi.org/10.1101/2020.06.18.20134536; this version posted June 20, 2020. The copyright holder for this preprint (which was not certified by peer review) is the author/funder, who has granted medRxiv a license to display the preprint in perpetuity.

It is made available under a CC-BY-NC-ND 4.0 International license.

Author contributions: DM, JLA \& LCP performed the statistical analysis and drafted the manuscript. CJH advised on the MRI images. All authors were involved in design of the study, interpretation of data and revision of the manuscript.

Funding

This work was funded by UK Medical Research Council award MR/S009892/1 (PI Melzer), which

supports JLA. DM and LCP are supported by the University of Exeter Medical School, and in part by the University of Connecticut School of Medicine. SS is supported by the College of Life and Environmental Sciences, University of Exeter. Input from CLK, GAK and DCS was supported by the University of Connecticut. The authors acknowledge the use of the University of Exeter HighPerformance Computing (HPC) facility in carrying out this work.

Acknowledgements

This research was conducted using the UK Biobank Resource, under application 14631: the authors thank the UK Biobank participants and coordinators for this unique dataset.

All authors declare no conflicts of interest. 
medRxiv preprint doi: https://doi.org/10.1101/2020.06.18.20134536; this version posted June 20, 2020. The copyright holder for this preprint (which was not certified by peer review) is the author/funder, who has granted medRxiv a license to display the preprint in perpetuity.

It is made available under a CC-BY-NC-ND 4.0 International license .

Table 1: Characteristics of participants included in the imaging and disease analyses, by HFE genotype and sex

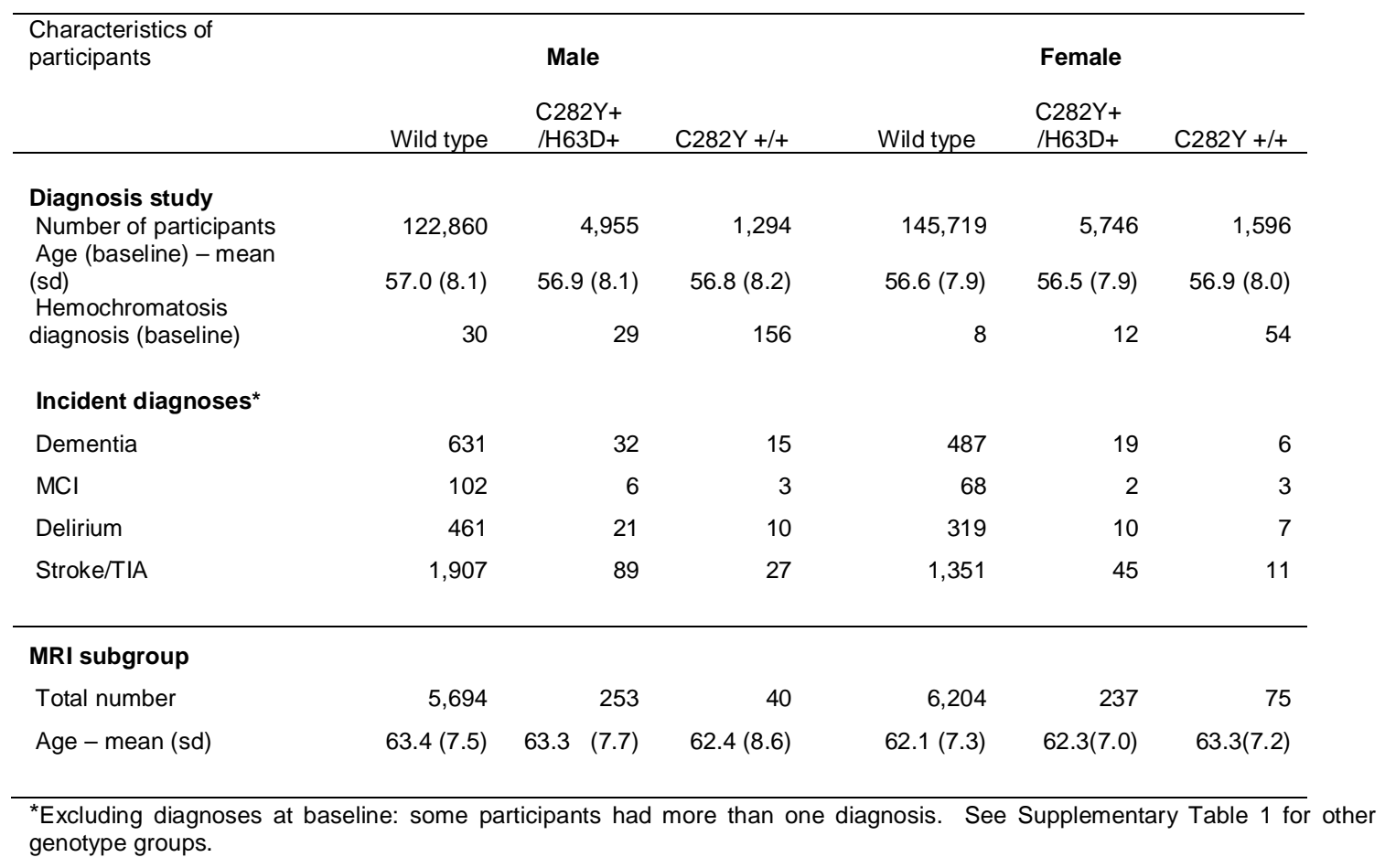


medRxiv preprint doi: https://doi.org/10.1101/2020.06.18.20134536; this version posted June 20, 2020. The copyright holder for this preprint (which was not certified by peer review) is the author/funder, who has granted medRxiv a license to display the preprint in perpetuity.

It is made available under a CC-BY-NC-ND 4.0 International license .

Table 2: Brain MRI median $\mathrm{T2}^{*}$ and gray matter volume associations from linear regression comparing HFE p.C282Y homozygote participants to controls with neither p.C282Y nor p.H63D, in males and females separately

\begin{tabular}{|c|c|c|c|c|c|}
\hline Outcome description & $\begin{array}{l}\text { beta } \\
\text { (standard } \\
\text { deviations) }\end{array}$ & $\begin{array}{l}95 \% \mathrm{Cl} \\
\text { (lower) }\end{array}$ & $\begin{array}{l}95 \% \mathrm{Cl} \\
\text { (upper) }\end{array}$ & $\begin{array}{l}\text { Unadjusted } \\
\text { p-value }\end{array}$ & $\begin{array}{l}\text { Multiple } \\
\text { testing } \\
\text { adjusted } \\
\text { p-value }\end{array}$ \\
\hline \multicolumn{6}{|l|}{ Males } \\
\hline \multicolumn{6}{|c|}{ Median T2* measures (37 homozygote vs. 5183 control) } \\
\hline thalamus & -1.04 & -1.33 & -0.76 & $1.0 \mathrm{E}-12$ & $4.9 \mathrm{E}-10$ \\
\hline putamen & -0.98 & -1.27 & -0.70 & $1.5 \mathrm{E}-11$ & 3.7E-09 \\
\hline caudate & -0.60 & -0.90 & -0.31 & $6.6 \mathrm{E}-05$ & $6.4 \mathrm{E}-03$ \\
\hline accumbens & -0.49 & -0.75 & -0.23 & 1.9E-04 & $1.0 \mathrm{E}-02$ \\
\hline hippocampus & -0.42 & -0.67 & -0.17 & $9.6 \mathrm{E}-04$ & 4.2E-02 \\
\hline \multicolumn{6}{|c|}{ Gray matter volume (40 homozygote vs.5692 control) } \\
\hline Putamen & -0.80 & -1.12 & -0.47 & 1.3E-06 & $2.2 \mathrm{E}-04$ \\
\hline Vermis IX Cerebellum & -0.75 & -1.12 & -0.38 & $6.6 \mathrm{E}-05$ & $6.4 \mathrm{E}-03$ \\
\hline V Cerebellum & -0.72 & -1.08 & -0.35 & $1.2 \mathrm{E}-04$ & 9.7E-03 \\
\hline Ventral Striatum & -0.55 & -0.84 & -0.26 & 2.1E-04 & $1.0 \mathrm{E}-02$ \\
\hline Vermis X Cerebellum & -0.76 & -1.15 & -0.36 & 1.7E-04 & 1.0E-02 \\
\hline
\end{tabular}

\section{Females}

Median T2* measures (69 homozygote vs. 5753 control)

$\begin{array}{llllll}\text { putamen } & -0.965 & -1.219 & -0.712 & 9.2 \mathrm{E}-14 & 4.5 \mathrm{E}-11 \\ \text { thalamus } & -0.776 & -0.997 & -0.555 & 6.2 \mathrm{E}-12 & 1.5 \mathrm{E}-09 \\ \text { caudate } & -0.683 & -0.955 & -0.412 & 8.3 \mathrm{E}-07 & 5.7 \mathrm{E}-05 \\ \text { pallidum } & -0.431 & -0.660 & -0.203 & 2.2 \mathrm{E}-04 & 8.4 \mathrm{E}-03\end{array}$

Gray matter volume (75 homozygote vs. 6203 control)

\begin{tabular}{llllll} 
Putamen & -0.815 & -1.065 & -0.565 & $1.7 \mathrm{E}-10$ & $2.7 \mathrm{E}-08$ \\
Vermis IX Cerebellum & -0.682 & -0.914 & -0.451 & $7.7 \mathrm{E}-09$ & $9.4 \mathrm{E}-07$ \\
Ventral Striatum & -0.602 & -0.813 & -0.391 & $2.4 \mathrm{E}-08$ & $2.3 \mathrm{E}-06$ \\
Vermis VI Cerebellum & -0.470 & -0.685 & -0.254 & $1.9 \mathrm{E}-05$ & $1.1 \mathrm{E}-03$ \\
Caudate & -0.487 & -0.734 & -0.240 & $1.1 \mathrm{E}-04$ & $5.1 \mathrm{E}-03$ \\
Vermis VIIla Cerebellum & -0.434 & -0.668 & -0.200 & $2.7 \mathrm{E}-04$ & $9.5 \mathrm{E}-03$ \\
V Cerebellum & -0.418 & -0.645 & -0.190 & $3.2 \mathrm{E}-04$ & $9.6 \mathrm{E}-03$ \\
Brain-Stem & -0.304 & -0.481 & -0.128 & $7.3 \mathrm{E}-04$ & $2.0 \mathrm{E}-02$ \\
Thalamus & -0.383 & -0.621 & -0.145 & $1.6 \mathrm{E}-03$ & $3.7 \mathrm{E}-02$ \\
\hline
\end{tabular}

Note: linear regression models for mean of left and right measures, adjusted for age, imaging assessment center, microarray, and genetic principal components 1-10. Beta = standard deviation difference in MRI imaging phenotype between C282Y homozygous group and the "wild type" group. Cls = confidence intervals. Adjusted P $=$ Benjamini-Hochberg adjusted p-values for 481 tests. See Supplementary Tables 2 and 3 for full results with other genotype groups. See Supplementary Tables 4 and 5 for analysis of left and right hemispheres separately. 
medRxiv preprint doi: https://doi.org/10.1101/2020.06.18.20134536; this version posted June 20, 2020. The copyright holder for this preprint (which was not certified by peer review) is the author/funder, who has granted medRxiv a license to display the preprint in perpetuity.

It is made available under a CC-BY-NC-ND 4.0 International license .

Figure 1: Control (left, 'WT') and p.C282Y homozygote (right) MRI T2 FLAIR axial images for male participants closest to respective mean putamen T2* values. In the highlighted square, cortical(1) and white matter(2) intensity appears similar in case and control but the p.C282Y homozygote image shows relative hypo-intensity (associated with iron deposition) in the putamen (3) and globus pallidus (4). Images provided by UK Biobank@ under license.

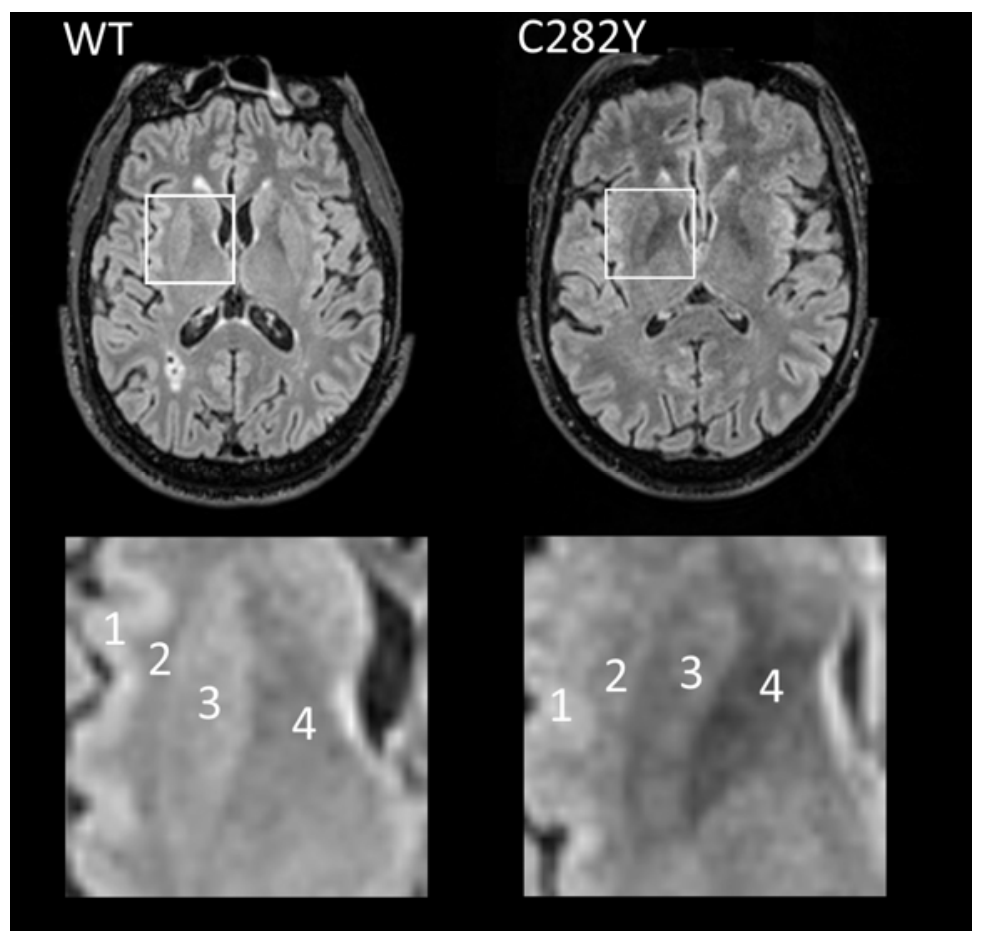

Notes: WT $=$ wild type or neither p.C282Y nor p.H63D mutations present. See details of image acquisition in Supplementary Information. 
medRxiv preprint doi: https://doi.org/10.1101/2020.06.18.20134536; this version posted June 20, 2020. The copyright holder for this preprint (which was not certified by peer review) is the author/funder, who has granted medRxiv a license to display the preprint in perpetuity.

It is made available under a CC-BY-NC-ND 4.0 International license.

Figure 2: Association between main HFE genotypes and incident diagnoses: Hazard ratios (95\%

Confidence intervals) compared to those with no HFE mutation.

\section{Males}

Stroke/TIA

Delirium

$\mathrm{MCl}$

Dementia

\section{Females}

Stroke/TIA

Delirium

Dementia
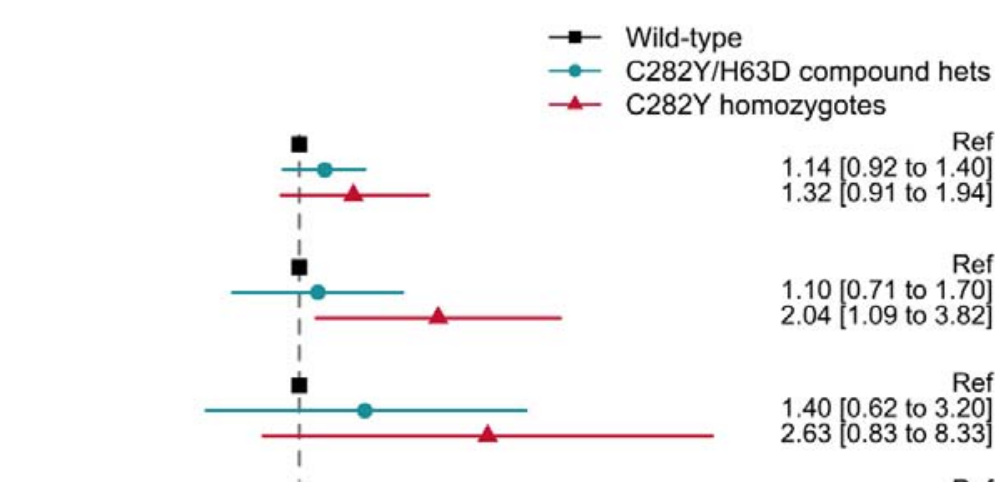

$\dot{1}$

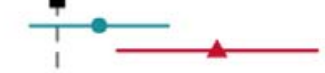

$2.63[0.83$ to 8.33$]$

$1.24[0.87$ to 1.77$]$

$2.27[1.36$ to 3.80$]$ $2.04[1.09$ to 3.82$]$

$1.40[0.62$ to 3.20$]$

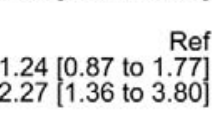

$0.84[0.63$ to 1 Ref 0.69 [0.38 to 1.24$]$

$0.79[0.42$ to 1.48 $1.79[0.85$ to 3.79$]$

$0.75[0.18$ Ref $3.61[1.13$ to 11.5$]$

0.98 Ref $0.96[0.43$ to 2.16$]$

Notes: Cox proportional hazards regression adjusted for age, imaging assessment center, microarray, and genetic principal components 1-10. Excluding each respective diagnosis at baseline. Full results for heterozygotes are presented in Supplementary Table 8. 
medRxiv preprint doi: https://doi.org/10.1101/2020.06.18.20134536; this version posted June 20, 2020. The copyright holder for this preprint (which was not certified by peer review) is the author/funder, who has granted medRxiv a license to display the preprint in perpetuity.

It is made available under a CC-BY-NC-ND 4.0 International license .

\section{References}

1. Ward RJ, Zucca FA, Duyn JH, et al. The role of iron in brain ageing and neurodegenerative disorders. Lancet Neurol. 2014;13(10):1045-1060. doi:10.1016/S1474-4422(14)70117-6

2. Derry PJ, Hegde ML, Jackson GR, et al. Revisiting the intersection of amyloid, pathologically modified tau and iron in Alzheimer's disease from a ferroptosis perspective. Prog Neurobiol. 2019:101716. doi:10.1016/j.pneurobio.2019.101716

3. Joppe $K$, Roser AE, Maass F, Lingor P. The contribution of iron to protein aggregation disorders in the central nervous system. Front Neurosci. 2019;13(JAN):1-11.

doi:10.3389/fnins.2019.00015

4. Arber CE, Li A, Houlden H, Wray S. Review: Insights into molecular mechanisms of disease in neurodegeneration with brain iron accumulation: Unifying theories. Neuropathol Appl Neurobiol. 2016;42(3):220-241. doi:10.1111/nan.12242

5. Nikseresht S, Bush Al, Ayton S. Treating Alzheimer's disease by targeting iron. $\mathrm{Br} \mathrm{J}$ Pharmacol. 2019. doi:10.1111/bph.14567

6. Crapper DR, McLachlan DRC, Kruck TPA, et al. Intramuscular desferrioxamine in patients with Alzheimer's disease. Lancet. 1991;337(8753):1304-1308. doi:10.1016/0140-6736(91)92978-B

7. Adams PC, Reboussin DM, Barton JC, et al. Hemochromatosis and Iron-Overload Screening in a Racially Diverse Population. NEnglJ Med. 2005;35217(17):1769-1778. doi:10.1056/NEJMoa041534

8. Powell LW, Seckington RC, Deugnier Y. Haemochromatosis. Lancet. 2016;388(10045):706716. doi:10.1016/S0140-6736(15)01315-X

9. Pilling LC, Tamosauskaite J, Jones G, et al. Common conditions associated with hereditary haemochromatosis genetic variants: Cohort study in UK Biobank. BMJ. 2019;364:k5222. doi:10.1136/bmj.k5222

10. Bomford A. Genetics of haemochromatosis. Lancet. 2002;360(9346):1673-1681. doi:10.1016/S0140-6736(02)11607-2

11. Vance E, Gonzalez JD, Miller JB, et al. Failure to detect synergy between variants in transferrin and hemochromatosis and Alzheimer's disease in large cohort. Neurobiol Aging. 2020:2018-2021. doi:10.1016/j.neurobiolaging.2020.01.013

12. Sudlow C, Gallacher J, Allen N, et al. UK Biobank: An Open Access Resource for Identifying the Causes of a Wide Range of Complex Diseases of Middle and Old Age. PLoS Med. 2015;12(3). doi:10.1371/journal.pmed.1001779

13. Alfaro-Almagro F, Jenkinson M, Bangerter NK, et al. Image processing and Quality Control for the first 10,000 brain imaging datasets from UK Biobank. Neuroimage. 2018;166(October 2017):400-424. doi:10.1016/j.neuroimage.2017.10.034

14. Duyn J. MR susceptibility imaging. J Magn Reson. 2013;229:198-207. doi:10.1016/j.jmr.2012.11.013

15. Sommerlad A, Perera G, Singh-Manoux A, Lewis G, Stewart R, Livingston G. Accuracy of general hospital dementia diagnoses in England: Sensitivity, specificity, and predictors of diagnostic accuracy 2008-2016. Alzheimer's Dement. 2018;14(7):933-943. 
medRxiv preprint doi: https://doi.org/10.1101/2020.06.18.20134536; this version posted June 20, 2020. The copyright holder for this preprint (which was not certified by peer review) is the author/funder, who has granted medRxiv a license to display the preprint in perpetuity.

It is made available under a CC-BY-NC-ND 4.0 International license .

doi:10.1016/j.jalz.2018.02.012

16. Wilkinson T, Schnier C, Bush K, et al. Identifying dementia outcomes in UK Biobank: a validation study of primary care, hospital admissions and mortality data. Eur $\mathrm{J}$ Epidemiol. 2019;34(6):557-565. doi:10.1007/s10654-019-00499-1

17. Morandi A, Davis D, Bellelli G, et al. The Diagnosis of Delirium Superimposed on Dementia: An Emerging Challenge. J Am Med Dir Assoc. 2017;18(1):12-18.

doi:10.1016/j.jamda.2016.07.014

18. Lin M, Zhao L, Fan J, et al. Association between HFE polymorphisms and susceptibility to Alzheimer's disease: A meta-analysis of 22 studies including 4,365 cases and 8,652 controls. Mol Biol Rep. 2012;39(3):3089-3095. doi:10.1007/s11033-011-1072-z

19. Tisato V, Zuliani G, Vigliano M, et al. Gene-gene interactions among coding genes of ironhomeostasis proteins and APOE-alleles in cognitive impairment diseases. PLoS One. 2018;13(3):1-21. doi:10.1371/journal.pone.0193867

20. De Jong LW, Van Der Hiele K, Veer IM, et al. Strongly reduced volumes of putamen and thalamus in Alzheimer's disease: An MRI study. Brain. 2008;131(12):3277-3285.

doi:10.1093/brain/awn278

21. Suzuki H, Venkataraman A V, Bai W, Guitton F, Guo Y, Dehghan A. Associations of Regional Brain Structural Differences With Aging, Modifiable Risk Factors for Dementia, and Cognitive Performance. JAMA Netw open. 2019;2(12):1-19. doi:10.1001/jamanetworkopen.2019.17257

22. Steffens DC, McDonald WM, Tupler LA, Boyko OB, Krishnan KRR. Magnetic resonance imaging changes in putamen nuclei iron content and distribution in normal subjects. Psychiatry Res - Neuroimaging. 1996;68(1):55-61. doi:10.1016/0925-4927(96)02834-X

23. Steffens DC, Tupler LA, Krishnan KRR. Magnetic resonance imaging signal hypointensity and iron content of putamen nuclei in elderly depressed patients. Psychiatry Res - Neuroimaging. 1998;83(2):95-103. doi:10.1016/S0925-4927(98)00032-8

24. Luo X, Mao Q, Shi J, Wang X, Li C-SR. Putamen gray matter volumes in neuropsychiatric and neurodegenerative disorders. World J psychiatry Ment Heal Res. 2019;3(1).

http://www.ncbi.nlm.nih.gov/pubmed/31328186\%0Ahttp://www.pubmedcentral.nih.gov/articlere nder.fcgi?artid=PMC6641567.

25. Fry A, Littlejohns TJ, Sudlow C, et al. Comparison of Sociodemographic and Health-Related Characteristics of UK Biobank Participants with the General Population. Am J Epidemiol. 2017;(September):4-12. doi:10.1093/aje/kwx246 